\title{
Workers' exposure to occupational heat during manual coffee harvesting
}

\author{
Lucas Deleon Ramirio ${ }^{1^{*}}$ (i) Paulo Henrique de Siqueira Sabino ${ }^{2}$ (1) \\ Geraldo Gomes de Oliveira Júnior ${ }^{1}$ (D) Adriano Bortolotti da Silva ${ }^{2}$ (D)
}

${ }^{1}$ Departamento de Segurança do Trabalho, Instituto Federal de Educação, Ciência e Tecnologia do Sul de Minas Gerais (IFSULDEMINAS), 37890-000, Muzambinho, MG, Brasil. E-mail: lucas.ramirio@ifsuldeminas.edu.br."Corresponding author.

${ }^{2}$ Programa de Pós-graduação em Agricultura Sustentável, Universidade José do Rosário Vellano (UNIFENAS), Alfenas, MG, Brasil.

ABSTRACT: This study evaluated the occupational exposure of workers to heat during manual harvesting of coffee. The case study was conducted between May to August. Occupational heat in coffee plantations was evaluated using the Wet Bulb Globe Temperature (WBGT) method and the metabolic rate. The WBGT was obtained using the TGD 400 thermal stress meter. The determined WBGT values were compared to two standards: the Occupational Hygiene Standard (NHO) 06 and Regulatory Norm (NR) 09. For acclimatized workers, the exposure limit was not exceeded at any time during the evaluated period. Fornon-acclimatized workers, the exposure limit was not exceeded only in July.

Key words: acclimatization, coffee, occupational heat, WBGT.

Exposição de trabalhadores ao calor ocupacional durante a colheita manual do cafeeiro

RESUMO: O presente trabalhado teve como objetivo avaliar a exposição ocupacional de trabalhadores ao calor durante a colheita manual do cafeeiro. $O$ estudo de caso foi desenvolvido entre os meses de maio a agosto. Avaliou-se o calor ocupacional em lavoura cafeeira através do método do Índice Bulbo Úmido Termômetro de Globo (IBUTG) e taxa metabólica. O IBUTG foi obtido utilizando o medidor de estresse térmico TGD 400. Os valores do IBUTG determinados foram comparados com duas normativas: Norma de Higiene Ocupacional (NHO) 06 e Norma Regulamentadora (NR) 09. Para trabalhadores aclimatizados o limite de exposição não foi superado em nenhum momento do período avaliado. Em relação aos trabalhadores não aclimatizados o limite de exposição não foi superado apenas em julho.

Palavras-chave: aclimatização, cafeicultura, calor ocupacional, IBUTG.

Occupationally, workers may be exposed to high temperatures and intense physical activities that may be harmful to their health. The health-related consequences have not received proper attention from employees and employers (NERBASS et al., 2017). Exposure to heat during the workday is considered one of the main problems to workers' health, reducing performance and harming their general well-being (KRISHNAMURTHY et al., 2017). Thus, it is necessary to measure heat indices to decrease the effects of heat exposure on workers' health.

In this context, knowing the agent of occupational heat to which coffee pickers may be exposed, is important for reducing the heat-related occupational risks. Therefore, the objective of this study was to evaluate the workers' occupational exposure to heat during the manual coffee harvest.

This case study was conducted in the experimental area of the Federal Institute of Education, Science and Technology of Southern Minas Gerais (IFSULDEMINAS), Inconfidentes Campus, MG, Brazil, located at $22^{\circ} 18^{\prime} 38.5^{\prime \prime} \mathrm{S}$ and $46^{\circ} 20^{\prime} 09.9^{\prime \prime} \mathrm{W}$ at an altitude of 869 meters.

The study was conducted from May to August in a coffee plantation (Coffea arabica L) cv. Catuai Vermelho, aged 10 years, mean plant height 1.5 $\mathrm{m}$, spaced $2.0 \mathrm{~m} \times 1.0 \mathrm{~m}$, occupying an area of 2.0 ha.

The NHO 06 methodology defines the technical criteria for evaluating occupational exposure 
to heat including the workers' thermal overload, action level, exposure limit, and acclimatization, was used.

The evaluation of occupational heat exposure was performed by simulating a worker performing the activities involved in manual coffee harvesting such as the tasks of opening the cloth, stripping the coffee fruit, shaking it to remove impurities, filling the bags, and transporting them to the big containers. The metabolism rate determined according to $\mathrm{NHO} 06$ for moderate manual work, was used to simulate a worker performing the activities involved in manual coffee harvesting (FUNDACENTRO, 2017) and the measured rate was $468 \mathrm{~W}$.

The data were collected using a heat stress meter with $0.1{ }^{\circ} \mathrm{C}$ resolution and $\pm 0.5^{\circ} \mathrm{C}$ accuracy (MOD: TGD - 400), consisting of wet bulb (wbt), dry bulb (dbt), and globe thermometers (gt). The equipment was mounted on a tripod and installed at a central point of the field with greater sun exposure and the thermometers were positioned at a height of $1.70 \mathrm{~m}$, which is considered the median height of the workers by the IBGE (2009). The evaluations were performed on days with no clouds to avoid the influence of shading at the evaluation point (FUNDACENTRO, 2017).

The data were collected by the data logging system of the equipment, which quantified the Wet Bulb Globe Temperature (WBGT) at every 60 minutes, between 7:00 am and 4:00 pm, with a total of four days of evaluations in each of the months studied (May/June/July/August).
As determined by Fundacentro (2017) and the American Conference of Governmental Industrial Hygienists (ACGIH, 2018), the WBGT evaluation with solar load was expressed in ${ }^{\circ} \mathrm{C}$, (Equation 1) as follows:

$\mathrm{WBGT}=0.7 \mathrm{wbt}+0.2 \mathrm{gt}+0.1 \mathrm{dbt}$

wbt $=$ natural wet bulb temperature $\left({ }^{\circ} \mathrm{C}\right)$

$\mathrm{gt}=$ globe temperature $\left({ }^{\circ} \mathrm{C}\right)$

$\mathrm{dbt}=$ dry bulb temperature (air temperature ${ }^{\circ} \mathrm{C}$ ).

The WBGT values obtained were compared with two norms, the NHO 06 and the NR 09. These standards determine the action level and exposure limit for non-acclimatized workers to be $22.1{ }^{\circ} \mathrm{C}$ and the exposure limit for acclimatized workers to be $25.9^{\circ} \mathrm{C}$, for performing activities with a metabolic rate of $468 \mathrm{~W}$. It is noteworthy that acclimatized workers are defined as those who have undergone physiological adaptation by means of successive and gradual heat exposures that aim to reduce the thermal overload caused by thermal stress (FUNDACENTRO, 2017).

The WBGT data were subjected to the Shapiro-Wilk test for normality analysis. The data presented normal distribution $(\mathrm{P}>0.05)$ and were subjected to analysis of variance. The interaction between the evaluated months and times was analyzed. The data were subjected to the Scott-Knott test at 5\% significance using the $\mathrm{R}$ software version 3.2.4 (R CORE TEAM, 2016).

There was a significant effect in the interaction between the evaluation times and months on the mean WBGT index value $(\mathrm{gl}=24 ; \mathrm{HR}=1.31$; $\mathrm{P}<0.05$ ) (Table 1). The lowest WBGT values during

Table 1 - Mean Wet Bulb Globe Temperature (WBGT) values ( \pm standard error) collected fromthe coffee plantation from May to August.

\begin{tabular}{|c|c|c|c|c|}
\hline & May & June & July & August \\
\hline Time & WBGT ${ }^{\circ} \mathrm{C}^{*}$ & WBGT ${ }^{\circ} \mathrm{C}^{*}$ & WBGT ${ }^{\circ} \mathrm{C}^{*}$ & WBGT ${ }^{\circ} \mathrm{C}^{*}$ \\
\hline $7: 00$ to $7: 59 \mathrm{am}$ & $16.04 \pm 0.22 \mathrm{~A} \mathrm{~d}$ & $16.83 \pm 1.08 \mathrm{~A} \mathrm{c}$ & $13.56 \pm 0.53 \mathrm{~B} \mathrm{~d}$ & $15.38 \pm 0.29 \mathrm{Ad}$ \\
\hline $8: 00$ to $8: 59$ am & $19.00 \pm 0.32 \mathrm{~A} \mathrm{c}$ & $19.9 \pm 1.04 \mathrm{~A} \mathrm{~b}$ & $17.42 \pm 0.45 \mathrm{~B} \mathrm{c}$ & $18.02 \pm 0.57 \mathrm{~B} \mathrm{c}$ \\
\hline $9: 00$ to $9: 59$ am & $20.45 \pm 0.29 \mathrm{~A} \mathrm{c}$ & $21.26 \pm 0.66 \mathrm{~A} \mathrm{a}$ & $19.53 \pm 0.21 \mathrm{~A} \mathrm{~b}$ & $19.61 \pm 0.5 \mathrm{~A} \mathrm{~b}$ \\
\hline $10: 00$ to $10: 59 \mathrm{am}$ & $21.53 \pm 0.3 \mathrm{~A} \mathrm{~b}$ & $22.56 \pm 0.65 \mathrm{~A} \mathrm{a}$ & $20.59 \pm 0.49 \mathrm{~A} \mathrm{~b}$ & $20.65 \pm 0.63 \mathrm{~A} \mathrm{~b}$ \\
\hline $11: 00$ to $11: 59 \mathrm{am}$ & $22.85 \pm 0.27 \mathrm{~A} \mathrm{a}$ & $22.87 \pm 0.73 \mathrm{~A} \mathrm{a}$ & $21.70 \pm 0.38 \mathrm{~A} \mathrm{a}$ & $21.81 \pm 0.66 \mathrm{~A} \mathrm{a}$ \\
\hline $12: 00$ to $12: 59 \mathrm{pm}$ & $23.53 \pm 0.34 \mathrm{~A} \mathrm{a}$ & $23.35 \pm 1.35 \mathrm{~A} \mathrm{a}$ & $21.96 \pm 0.52 \mathrm{~A} \mathrm{a}$ & $22.29 \pm 0.63 \mathrm{~A} \mathrm{a}$ \\
\hline $1: 00$ to $1: 59 \mathrm{pm}$ & $23.78 \pm 0.56 \mathrm{~A} \mathrm{a}$ & $23.69 \pm 1.62 \mathrm{~A} \mathrm{a}$ & $21.87 \pm 0.39 \mathrm{~A} \mathrm{a}$ & $22.69 \pm 0.62 \mathrm{~A} \mathrm{a}$ \\
\hline $2: 00$ to $2: 59 \mathrm{pm}$ & $23.61 \pm 0.11 \mathrm{~A} \mathrm{a}$ & $22.97 \pm 1.75 \mathrm{~A} \mathrm{a}$ & $21.25 \pm 0.74 \mathrm{~B} \mathrm{a}$ & $22.49 \pm 0.75 \mathrm{~A} \mathrm{a}$ \\
\hline $3: 00$ to $3: 59 \mathrm{pm}$ & $19.59 \pm 0.32 \mathrm{~A} \mathrm{c}$ & $20.54 \pm 0.85 \mathrm{~A} \mathrm{a}$ & $21.25 \pm 0.52 \mathrm{~A} \mathrm{a}$ & $21.74 \pm 0.66 \mathrm{~A} \mathrm{a}$ \\
\hline
\end{tabular}

${ }^{*}$ Means followed by the same lower-case letters in the columns and capital letters in the rows do not differ by the Scott-Knott test at the $5 \%$ probability level. 
manual coffee harvest for the months evaluated were recorded from 7:00 am to 7:59 am.

The most unfavorable thermal conditions for May, July, and August were found after 11:00 am. However, there was a WBGT reduction in May from 3:00 pm to 3:59 pm, with $19.59^{\circ} \mathrm{C}$. In June, the highest WBGT index was recorded between 9:00 am to $3: 59 \mathrm{pm}$. The most unfavorable working conditions should be observed and measures adopted to prevent occupational heat exposure (FUNDACENTRO, 2017; ACGIH, 2018).

The months evaluated presented different WBGT from 7:00 am to 7:59 am, 8:00 am to 8:59 am, and 2:00 pm to 2:59 pm. The lowest WBGT values were found in July and August from 7:00 am to 7:59 am and 8:00 am to 8:59 am. The lowest WBGT values were also recorded from 2:00 pm to 2:59 pm in July $\left(21.25 \pm 0.74{ }^{\circ} \mathrm{C}\right)$.
Comparing the data obtained to that of the NHO 06 and NR 09, the results showed that the occupational exposure limit for acclimatized workers was not exceeded at any time during the workday in the months evaluated (Figure 1). The same results were reported for non-acclimatized workers in July when there were no recorded values above the exposure limit. However, the values obtained in May from 11:00 am to $2: 59 \mathrm{pm}$, June from 10:00 am to $2: 59 \mathrm{pm}$, and August from 12:00 to 2:59 pm, were above the exposure limit for non-acclimatized workers (Figure 1).

Under the study conditions, the most unfavorable thermal conditions were observed between 11:00 am and 2:59 pm in the months evaluated. For acclimatized workers, the exposure limit was not exceeded at any time during the evaluated periods. In May, June, and August, non-acclimatized workers were exposed to heat above the exposure limit.

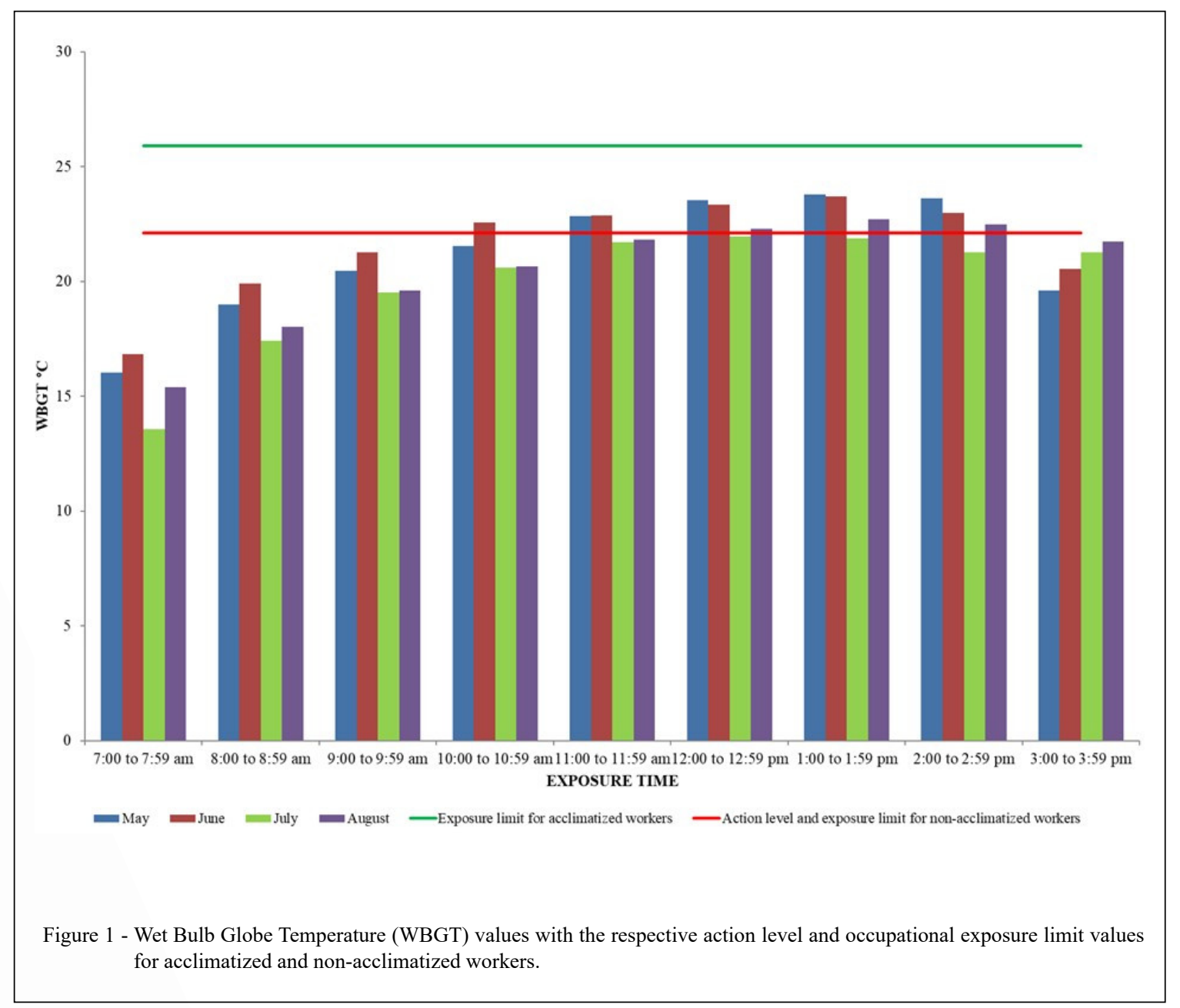

Ciência Rural, v.51, n.11, 2021. 


\section{ACKNOWLEDGMENTS}

The present work was carried out with the support of the Coordenação de Aperfeiçoamento de Pessoal de Nível Superior (CAPES).

\section{DECLARATION OF CONFLICT OF INTEREST}

The authors declare no conflict of interest. The founding sponsors had no role in the study design, data collection, analysis, results interpretation, manuscript writing or in the decision to publish the results.

\section{AUTHORS' CONTRIBUTION}

All authors contributed equally to the design and writing of this manuscript.

\section{REFERENCES}

ASSOCIAÇÃO BRASILEIRA DE HIGIENISTAS OCUPACIONAIS. TLVs and BEIs - Translation of the exposure limits (TLVs) for chemical substances and physical agents and biological exposure indices (BEIs) of the ACGIH. ACGIH. [S.1.: s.n. ], 2018.

FUNDAÇÃO JORGE DUPRAT FIGUEIREDO DE SEGURANÇA E MEDICINA DO TRABALHO FUNDACENTRO. Norma de higiene ocupacional: NHO 06 Procedimento Técnico: avaliação da exposição ocupacional ao calor. São Paulo, 2017, 48 p.

IBGE. Economic Statistics. 2018. Available from: <https:// agenciadenoticias.ibge.gov.br>. Accessed: Dec. 09, 2018.

KRISHNAMURTHY, M. et al. Occupational Heat Stress Impacts on Health and Productivity in a Steel Industry in Southern India. Safety And Health At Work, [s.1.], v.8, n.1, p.99-104, mar. 2017. Available from: <https://www.sciencedirect.com/science/article/pii/ S2093791116302220>. Accessed: Feb. 28, 2020. doi: 10.1016/j. shaw.2016.08.005.

NERBASS, F. B. et al. Occupational Heat Stress and Kidney Health: From Farms to Factories. Kidney International Reports, [s.1.], v. 2 , n.6, p.998-1008, nov. 2017. Available from: $<$ https://www. ncbi.nlm.nih.gov/pmc/articles/PMC5733743/>. Accessed: Feb. 20, 2020. doi: 10.1016/j.ekir.2017.08.012.

R DEVELOPMENT CORE TEAM. R Foundation for Statistical Computing, Vienna, Austria, 2016. 